\title{
Origin and structure of the Kranz tissue in bracts of Cyperus giganteus Vahl (Cyperaceae)
}

\author{
ANA CLAUDIA RODRIGUES ${ }^{1,2}$ and MARIA EMÍLIA MARANHÃO ESTELITA ${ }^{2}$
}

(received: December 25, 2001; accepted: August 28, 2003)

\begin{abstract}
Origin and structure of the Kranz tissue in bracts of Cyperus giganteus Vahl (Cyperaceae)). Cyperus giganteus shows Kranz anatomy of the clorocyperoid type or with two sheaths, one internal, adjacent to the vascular system and known as Kranz sheath, with thin-walled cells and a large number of organelles, mainly chloroplasts; and an external sheath, the mestome sheath or endodermis, the cells of which present thickened walls, are without chloroplasts and possess a suberin lamella, together with the casparian strip which are detected in early stages of differentiation. The development of the vascular bundles shows the Kranz sheath originating from the procambial as well as the mestome sheath. The chloroplasts of the Kranz cells are relatively larger, with convoluted thylakoids and a prominent peripheral reticulum, while the chloroplasts of the mesophyll cells are relatively smaller, with thylakoids forming grana and a sparse peripheral reticulum. These ultrastructural characteristics show similarities to those of other species of the genus Cyperus.
\end{abstract}

Key words - bracts, clorocyperoid, Cyperaceae, Cyperus giganteus, Kranz

RESUMO - (Origem e estrutura do tecido Kranz em brácteas de Cyperus giganteus Vahl (Cyperaceae)). Cyperus giganteus apresenta estrutura Kranz do tipo clorociperoide, ou seja, com duas bainhas: uma interna, adjacente ao sistema vascular ou bainha Kranz, que contém muitas organelas, principalmente cloroplastos; e uma bainha externa, a bainha mestoma ou endoderme com células de paredes espessadas, lamela de suberina, e que apresenta estrias de Caspary perceptíveis em estágios jovens de diferenciação. As bainhas Kranz e mestoma originam-se do cordão procâmbial. Os cloroplastos das células Kranz são relativamente maiores, com tilacóides convolutos e retículo periférico conspícuo; os cloroplastos das células do mesofilo são relativamente menores, com tilacóides formando granos e retículo periférico inconspícuo. Estas características corroboram àquelas de outras espécies do gênero Cyperus.

Palavras-chave - brácteas, clorociperóide, Cyperaceae, Cyperus giganteus, Kranz

\section{Introduction}

Cyperus giganteus Vahl is a perennial species which generally occupies a marshy habitat. The plant possesses relatively thin, delicate, roots, borne on plagiotropic rhizomes (Rodrigues \& Estelita 2002); the leaves are absent and, as a result, the scape is the principal photosynthetic organ. In the Pantanal region of Mato Grosso do Sul, western Brazil, C. giganteus is popularly known as "piri", and forms part of the family of plants known as "pirizal" (Allem \& Valls 1987).

The term Kranz ("crown") was first used by Haberlandt (1914), in the analysis of species of Cyperus and of Gramineae. The species which present the Kranz structure generally carry out $\mathrm{C}_{4}$ photosynthesis under conditions of stress, particularly in high temperatures. It is known that this type of metabolism represents an

\footnotetext{
1. Universidade de São Paulo, Departamento de Botânica, Instituto de Biociências, Caixa postal 11461, 05422-970 São Paulo, SP, Brasil.

2. Corresponding author:estelita@ib.usp.br
}

alternative that has been developed by certain plants to overcome the $\mathrm{CO}_{2}$ deficiency of the $\mathrm{C}_{3}$ pathway.

Amongst the monocotyledons the Kranz syndrome is only found in the Poaceae (Gramineae) and Cyperaceae (Welkie \& Caldwell 1970) families. Four different types of Kranz structures are found in the Cyperaceae (Takeda et al. 1980, Ueno \& Koyama 1987, Bruhl et al. 1987, Soros \& Dengler 2001) which vary according to the number and function of the sheaths which surround the vascular bundles.

With regard to the origin of the Kranz tissue, Dengler et al. (1985) found that, in $\mathrm{C}_{4}$ species of the Gramineae, the Kranz sheath is derived from the ground meristem and is homologous to the bundle sheath of $\mathrm{C}_{3}$ species, while the internal sheath, or mestome, originates from the outermost layer of the procambium. The origin of the Kranz tissue in the majority of Cyperaceae appeared to be clarified by Brown (1975) and lay in a modification of the parenchymal cells of the vascular bundle; the sheath was believed, therefore, to be of procambial origin. In addition, Carolin et al. (1977) asserted that the Kranz cells in Cyperaceae species are modified parenchymal cells of the phloem and xylem; such an origin was subsequently confirmed by Estelita (1992). 
The ultrastructural analysis of the different types of Kranz in Cyperaceae has revealed differences amongst the organelles, mainly between the chloroplasts of the Kranz sheath cells and those of the cells of the mesophyll (Carolin et al. 1977, Ueno et al. 1988, Estelita 1992). According to Estelita (1993), the ultrastructural characteristics of the Kranz cells, especially of their chloroplasts, can be used in the classification of the Cyperaceae.

The aim of this study was to investigate the origin and the structural characteristics of the Kranz tissue in bracts of $C$. giganteus, thereby contributing to a greater understanding of the structural variation exhibited by the Cyperaceae.

\section{Material and methods}

Specimens of $C$. giganteus were collected in the Pantanal region in Mato Grosso do Sul, western Brazil. The material are registered under the catalogue numbers SPF 138.170 and 138.174.

Samples from the rhizome apex in different stages of development and from mature bracts were fixed in FAA 50 (Johansen 1940) for 72 hours and afterwards stored in $70 \%$ ethanol.

In order to study development, permanent slides were prepared by dehydration of the tissue in a tertiary butanol series (Johansen 1940). The material was embedded in paraffin and sections were stained with safranin and astra blue (Bukatsch 1972).

Mature bracts were embedded in historesin by passing the tissue through an ethyl alcohol series, beginning with the alcohol used as the fixative, followed by embedding in historesin with $95 \%$ ethanol (1:1) and undiluted historesin; sections were cut and rehydrated in water before being stained with toluidine blue.

Sections were cut on a Leica Reichert-Jung 2040 microtome, equipped with a steel blade. The thickness of the sections varied from 8 to $10 \mu \mathrm{m}$ for the paraffin-embedded material, and from 3 to $5 \mu \mathrm{m}$ for the material embedded in historesin, which was cut using a glass knife.

Semi-permanent slides of mature bracts were prepared by double-stained with safranin and astra blue (Bukatsch 1972) and mounting in 50\% glycerine. The Casparian strip was recognized in young bracts stained with crystal violet and orange G. Records were obtained with an Olympus-Vanox microscope.

For ultrastructural analysis, samples of mature bracts were fixed in 2,5\% glutaraldehyde and post-fixed with osmium tetroxide in $0,1 \mathrm{M}$ phospate buffer at $\mathrm{pH} 7$; tissue was dehydrated by passing through an ethanol series before embedding in Spurr resin (Spurr 1969). Semi-thin and ultrathin sections were obtained and these were stained with uranyl acetate (Watson 1958) and lead citrate (Reynolds 1963) before being examined in a Siemens Elmiskop I electron microscope.

\section{Results}

Transverse sections of the stem tip show overlapping the bracts in a imbricated pattern (figure 1). The procambial strands are located closest to the epidermis of the upper face (figure 2); of these, vascular bundles of three different diameters can be observed with the largest diameter bundles showing early differentiation in relation to the others (figures 2 and 3 ).

In the differentiation of the vascular bundles, first, the parenchymal cells are arranged around the procambial strands and it is possible to identify the anticlinal division in to cells that will form a part of the mesophyll (figure 3, arrow).

In parallel with these events, the more peripheral layer of the procambial strands undergo periclinal division forming the mestome sheath or endodermis (figures 3 and 4), in which the Casparian strip are discernible (figure 5 arrows). At the same time, the same procambial strands gives rise to the Kranz sheath, which is situated within the mestome sheath (figures 3, 6, 7). The differentiation of the chlorenchyma is observed around the mestome sheath (figures 3-7).

In the vascular bundles of largest diameter, differentiation of the phloem adjacent to the Kranz sheath occurs first, and then, followed by the beginning of the metaxylem diferentiation (figure 3). Subsequently, phloem and metaxylem differentiation is completed (figures 4-6), with protoxylem gaps in the largest diameter bundles (figures 4,6).

The cells of the mesophyll become elongated, thus forming the radial mesophyll, and at the end of differentiation, it can be seen that the vascular bundles of various diameters exhibit Kranz structure and interveinal distances, in which the bundles are separated from each other by one or two layers of the mesophyll cells (figures 4, 6). Generally, the largest diameter bundles are interspersed by 2 or 3 bundles of smaller diameter (figure 2).

The bundles of largest diameter exhibit a Kranz sheath interrupted by elements of the metaxylem (figure 6), while the smaller diameter bundles present a continuous Kranz sheath (figure 7). The cells of the mestome sheath are thickened with maturity. However, the cells which surround the elements of the xylem exhibit thinner walls in relation to those cells which surround the phloem elements. 
The chlorenchyma is arranged around the mestome sheath in a radial pattern. The cells of the Kranz sheath have a greater diameter and thinner walls in relation to the cells of the mestome sheath, particularly in the smaller diameter bundles (figure 7).

The ultrastructural analysis reveals the presence of numerous chloroplasts and mitochondria in the cells of the Kranz sheath. The chloroplasts are more conspicuous than those of the chlorenchyma cells and the lamellar system is formed by convolute thylakoids without grana; the peripheral reticulum is prominent (figures 8,9). The chloroplasts of the chlorenchyma cells present a lamelar system organized in grana and the peripheral reticulum is practically unidentifiable (figure 10). Plasmodesmata region are identified between the cells of the Kranz sheath and those of the mestome sheath and between the cells of the mestome sheath and the cells of the radial mesophyll (figure 11). No
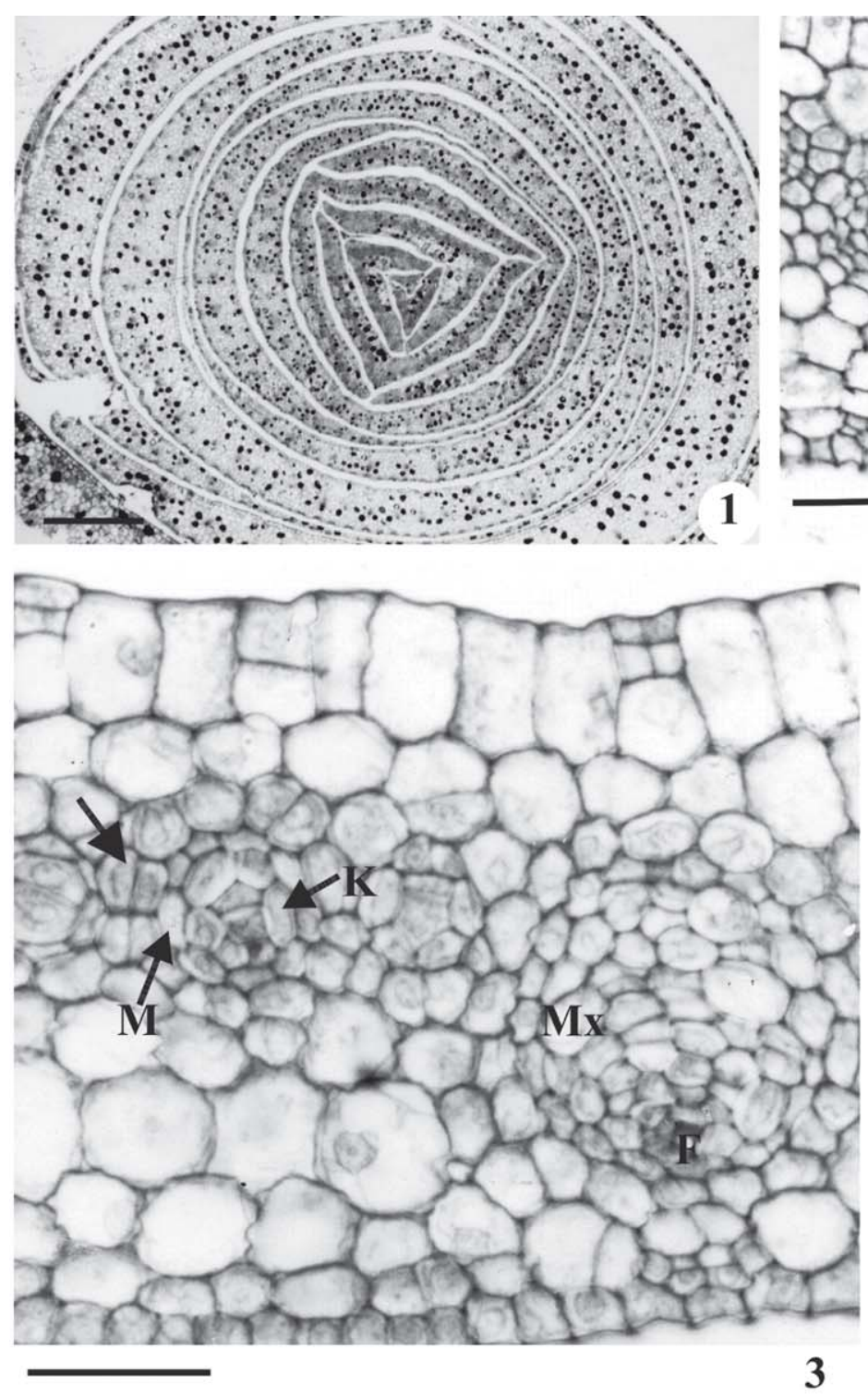
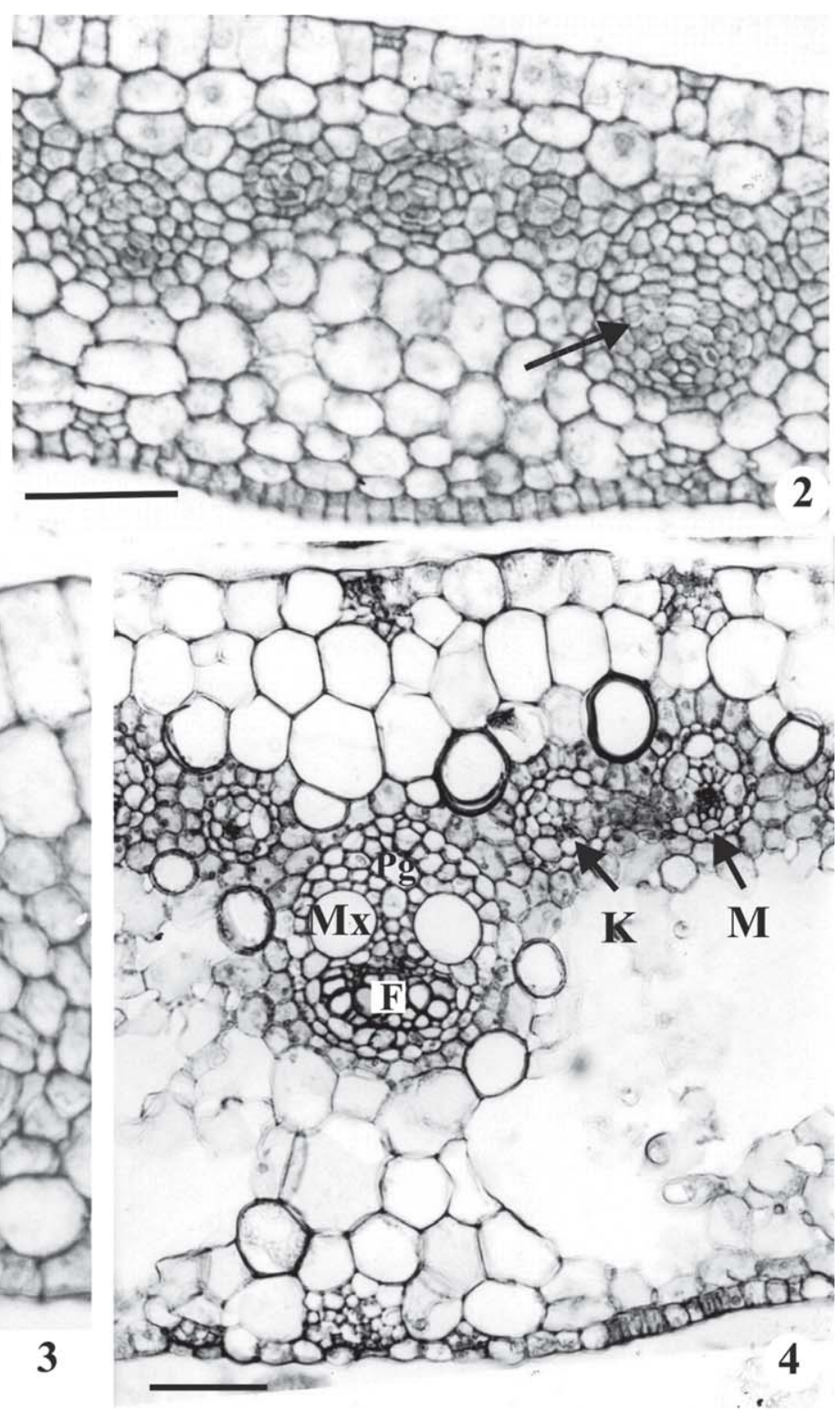

Figures 1-4. Cross-sections of the bracts. 1. Stem tip showing the imbricated arrangement of the bracts. 2-3. Immature bracts. 2. Showing differentiation of the vascular bundles with three different diameters nearest to the upper epidermis and early differentiation of the largest diameter bundles (arrow). 3. Smaller and larger vascular bundles showing the tissues differentiation. The arrow indicates anticlinal division. 4. Mature bract showing differentiated tissues. $(\mathrm{M}=$ mestome sheath; $\mathrm{K}=\mathrm{Kranz}$ sheath; $\mathrm{F}=$ phloem; $\mathrm{Mx}=$ metaxylem; $\mathrm{Pg}=$ protoxylem gaps). $\mathrm{Bars}=300 \mu \mathrm{m}(1), 60 \mu \mathrm{m}(2), 30 \mu \mathrm{m}(3,4)$. 


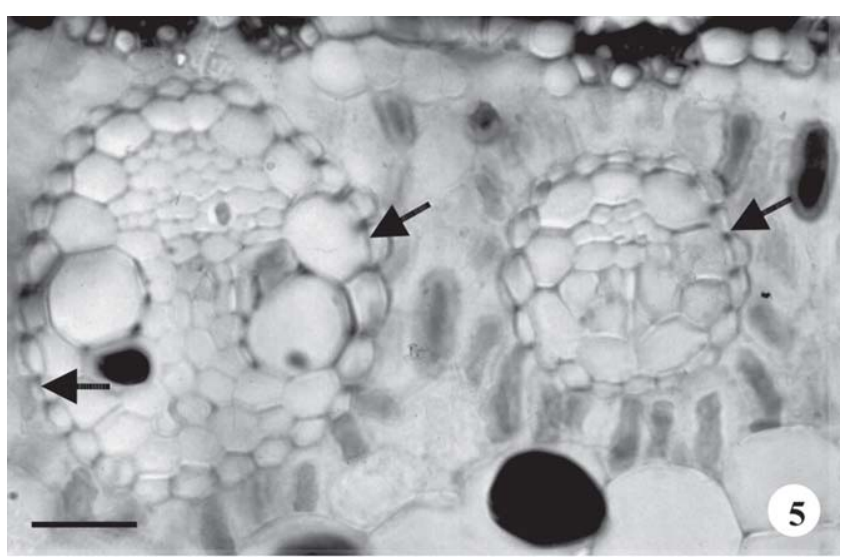

Figure 5. Cross-sections showing the Casparian strip in the endodermis (arrows). Bar $=10 \mu \mathrm{m}$.

plasmodesmata were observed between the Kranz cells, nor between the Kranz cells and the cells of the vascular tissue.

The cells of the mestome sheath show consistently thickened walls, with a number of electron dense layers; the outermost of these is the suberin lamella; it is possible that the multiple electron-dense layers of the wall contain the same substance (figure 11).

\section{Discussion}

Various studies on the leaf anatomy of Cyperaceae species have shown four different types of Kranz anatomy in the $\mathrm{C}_{4}$ species (Brown 1975, Carolin et al. 1977, Ueno et al. 1988, Bruhl \& Perry 1995). They can be classified in the following groups, depending on whether they exhibit two or three sheaths: Chlorocyperoid (presence of discontinuous Kranz and mestome sheaths), Rhynchosporoid (presence of a Kranz sheath, in place of the mestome sheath, and a parenchymal sheath), Fimbristyloid (presence of Kranz, mestome and parenchymal sheaths) and Eleocharoid (presence of continuous Kranz and mestome sheaths).

The genus Cyperus is categorised as a Clorocyperoid, presenting two sheaths, one internal, adjacent to the vascular system, known as the Kranz sheath, the cells of which are thin-walled and contain large numbers of organelles, particularly chloroplasts; and an external, or mestome sheath, with thick-walled cells which do not contain chloroplasts (Takeda et al. 1985). This arrangement is the opposite of that which is found in the Kranz grasses, in which the mestome sheath is located inside the Kranz sheath (Brown 1975).

Brown (1975), in an analysis of $\mathrm{C}_{4}$ species of Cyperaceae, informed that the Kranz sheath originated from the parenchyma of the vascular tissue. Estelita (1992), in a study of young leaves from Remirea maritima Aubl., found that the procambium gave rise to the vascular tissue and the Kranz sheath, thus providing support to the hypothesis of Brown. Carolin et al. (1977) observed that, in $\mathrm{C}_{3}$ species, the parenchymal cells external to the phloem and xylem often contained numerous and well-formed chloroplasts; the authors suggested that these parenchymal cells were probably the equivalent of Kranz cells. Similar findings have been reported in Eleocharis, the Kranz cells of which are derived from cells of the vascular parenchyma (Ueno \& Samejima 1989, Ueno et al. 1989). Soros \& Bruhl (2000) studying different types of Kranz anatomy in Cyperaceae, concluded that the Kranz sheath is always derived from the procambium, including the Rhynchosporoid type. Later, Soros \& Dengler (2001) in an analysis of several $\mathrm{C}_{3}$ and $\mathrm{C}_{4}$ Cyperaceae species concluded that Kranz sheath and mestoma are always derived from the procambium.

This study shows that in $C$. giganteus Vahl the Kranz cells originate directly from the procambium and the mestome sheath too. The short internerval distance observed in $C$. giganteus is also seen in $R$. maritma (Estelita 1993), represents an important aspect in the characterisation of $\mathrm{C}_{4}$ photosynthesis (Kanai \& Kashiwagi 1975); as it reduces the distance over which the exchange of metabolites takes place (Crookston 1980).

Greater differences between the chloroplasts of the Kranz cells and those of cells of the mesophyll are commonly found in monocotyledon $\mathrm{C}_{4}$ species (Estelita 1992). The convoluted thylakoids observed in C. giganteus have also been identified in other species of Cyperus (Carolin et al. 1977, Ueno et al. 1988). However, Estelita-Teixeira \& Handro (1987) did not find convoluted thylakoids in their analysis of Cyperus species. According to Carolin et al. (1977), the convolutions may increase the area of thylakoids-stroma interface and the starch grains do not appear to cause the distortions. According to Estelita (1993), the organisation of the thylakoids system may be of general use in the characterisation of these species. The chloroplasts of the radial mesophyll in C. giganteus show thylakoids with well-developed structured grana and a barely discernible peripheral reticulum, as observed in R. maritima (Estelita 1993) and C. obtusatus (Presl) Mattf. \& Kük. (Estelita-Teixeira \& Handro 1987).

The peripheral reticulum of the Kranz cells in C. giganteus is conspicuous, as noted by Ueno et al. (1988) in several $\mathrm{C}_{4}$ species of Cyperaceae. However, 
in $C$. giganteus the peripheral reticulum does not form vesicles ("dumbbell") as described by Carolin et al. (1977) for C. victoriensis C.B. Clarke and C. macrostachyos Lam. The occurrence of the peripheral reticulum in chloroplasts of the Kranz cells, especially those which are well developed and located at the margins of the chloroplasts adjacent to the cells of the mestome sheath, may be related to the rapid bidirectional transport of metabolites which is subject to high resistance because of the thick walls of the cells of the mestome sheath (Ueno et al. 1988).

In $C$. giganteus, no plasmodesmata were seen between the Kranz cells and the vascular tissue. According to Ueno et al. (1988), in species of Eleocharis plasmodesmata are rarely found amongst the Kranz cells and between the Kranz cells and cells of the xylem and phloem; however, plasmodesmata between adjacent Kranz cells were observed by Estelita (1992) in R. maritma.

According to Esau (1977), the bundle sheath in the angiosperms is an endodermis, despite the Casparian strip being frequently indistinguishable. $C$. giganteus exhibits Casparian strip in the cells of the mestome sheath, as observed by Van Fleet (1950) in young leaves of Gramineae and Cyperaceae. Estelita-Teixeira \& Handro (1987) observed three electron-dense regions in the cells of the mestome sheath of species of Cyperaceae, with one of these being the middle lamella. In $C$. giganteus the most electron-dense region in the cells of the mestome sheath corresponds to the suberin lamella, together with the remaining lamella. The outermost suberine lamella has also been described in species of Elocharis (Ueno et al. 1989) and Fimbristylis (Estelita 1999). The suberin lamella
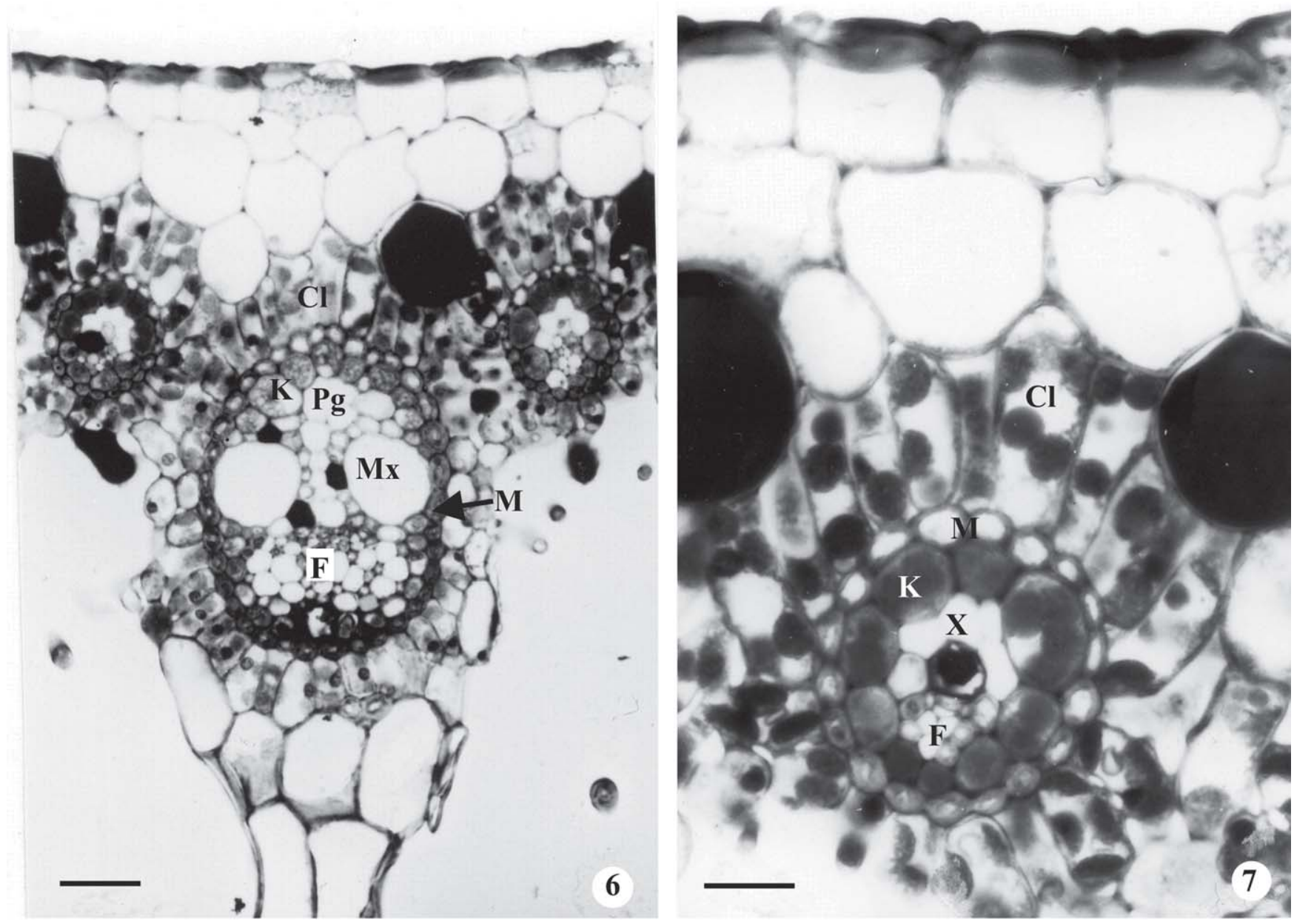

Figures 6-7. Cross-sections of the mature bracts. 6. Note the larger diameter bundle in which the Kranz sheath is interrupted by elements of the metaxylem. 7. Note the small diameter bundle in which the Kranz sheath is continuous. $(\mathrm{K}=\mathrm{Kranz}$ sheath; $\mathrm{M}=$ mestome sheath $\mathrm{Cl}=$ chlorenchyma; $\mathrm{F}=$ phloem; $\mathrm{Pg}=$ protoxylem gap; $\mathrm{Mx}=$ metaxylem; $\mathrm{x}=\mathrm{xylem}) . \mathrm{Bars}=40 \mu \mathrm{m}(6), 10 \mu \mathrm{m}(7)$. 
consists of a suberin polymer and waxes and is relatively impermeable to water (Soliday et al. 1979); it can also act as a barrier against the apoplastic diffusion of $\mathrm{CO}_{2}$ and, thus, maintains a high concentration of this gas in the Kranz cells (Carolin et al. 1977).
According to the analysis presented in this work, C. giganteus presents similar structural and ultrastructural characteristics to the other species of the genus, with the notable exception of the ultrastructure of chloroplasts in the Kranz sheath. The mestome sheath
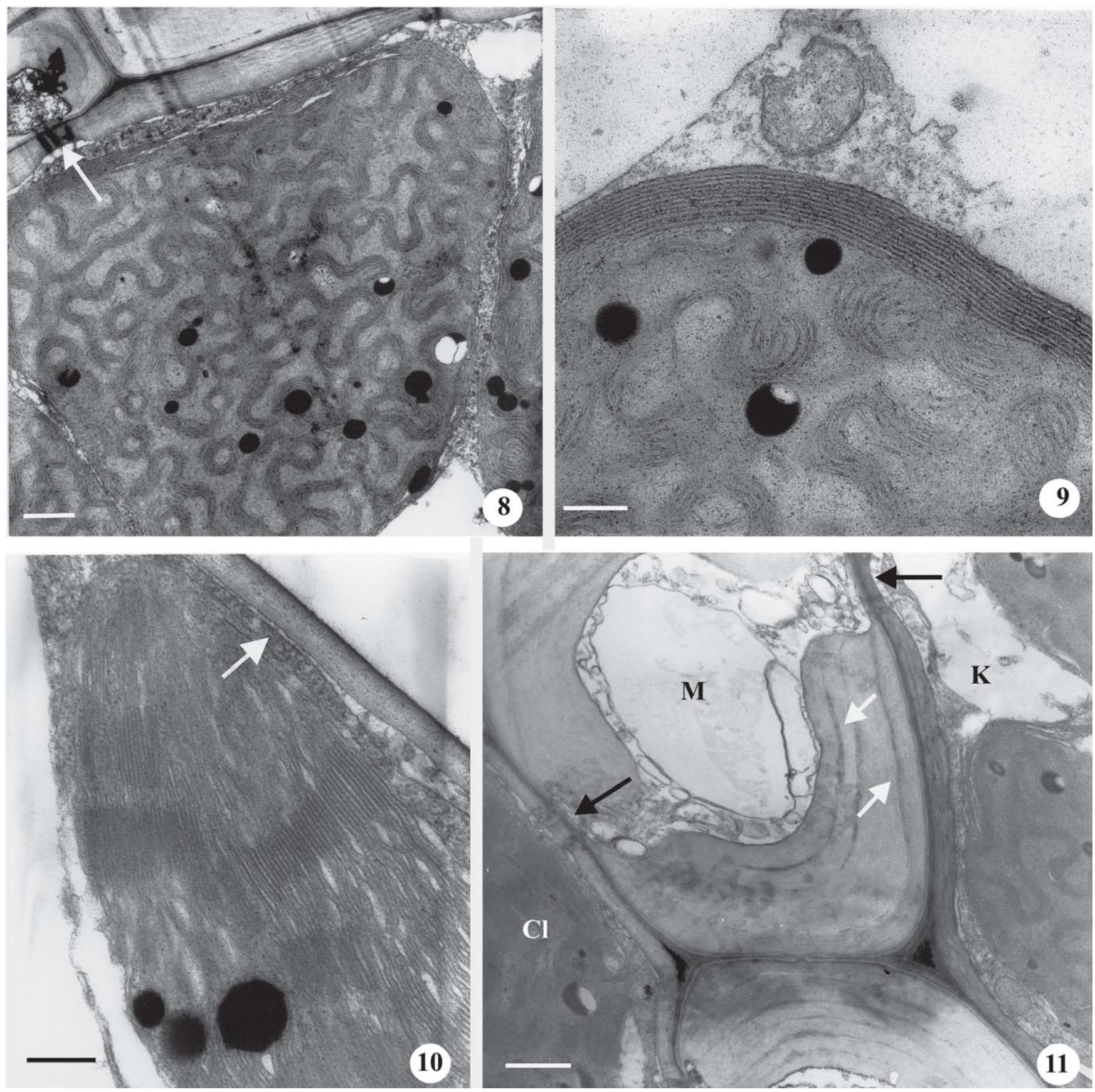

Figures 8-11. Electronmicrographs showing the Kranz structure. 8. Detail the chloroplasts in the Kranz cells with convoluted thylakoids and, also, plasmodesma region between Kranz cells and mestome cell (white arrow). 9. Detail of the prominent peripheral reticulum of the chloroplast in the Kranz cells. 10. Note the chloroplast of the chlorenchyma cells; the thylakoids forming grana and the barely discernible peripheral reticulum (white arrow). 11. Detail of the mestome cell showing plasmodesmata region (black arrows), between cells of the mestoma sheath with Kranz cells and chlorenchyma as well as suberin lamella (white arrows). $(\mathrm{K}=\mathrm{Kranz}$ sheath; $\mathrm{M}=$ mestome sheath; $\mathrm{Cl}=$ chlorenchyma). $\mathrm{Bars}=3 \mu \mathrm{m}(8), 1,5 \mu \mathrm{m}(9,10), 5 \mu \mathrm{m}(11)$. 
which is presented in three types of Kranz anatomy in the Cyperaceae might contribute as a barrier for diffusion of the $\mathrm{CO}_{2}$ from Kranz sheath to intercellular spaces (Soros \& Dengler 1998). In this paper it has been proven that the mestome sheath is a true endodermis because of the Casparian strips and suberin lamella. It means that the barrier might begin earlier in the differentiation due to the Casparian strips.

Acknowledgements - The authors thank FAPESP (process 97/05516-0) and CNPq (process 30710/84) for supporting and Electron Microscopy Center of the Biosciences Institute, for the use of the transmission electron microsope.

\section{References}

ALLEM, A.C. \& VALLS, J.F.M. 1987. Recursos forrageiros nativos do Pantanal Mato-Grossense. Empresa Brasileira de Pesquisa Agropecuária - Embrapa - Centro Nacional de Recursos Genéticos, Brasília.

BROWN, W.V. 1975. Variations in anatomy, associations and origins of Kranz tissue. American Journal of Botany 62:395-402.

BRUHL, J.J. \& PERRY, S. 1995. Photosynthetic pathwayrelated ultrastructure of $\mathrm{C}_{3}, \mathrm{C}_{4}$ and $\mathrm{C}_{3}-\mathrm{C}_{4}$ intermediate sedges (Cyperaceae), with special reference to Eleocharis. Australian Journal of Plant Physiology 22:521-530.

BRUHL, J.J., STONE, N.E. \& HATTERSLEY, P.W. 1987. C 4 acid decarboxylation enzymes and anatomy in sedges (Cyperaceae): first record of NAD-malic enzyme species. Australian Journal of Plant Physiology 14:719-728.

BUKATSCH, F. 1972. Bemerkungen zur Doppelfärbung Astrablau-Safranin. Mikrokosmos 6:255.

CAROLIN, R.C., JACOBS, S.W.L. \& VESK, M. 1977. The ultrastructure of Kranz cells in the family Cyperaceae. Botanical Gazette 138:413-419.

CROOKSTON, R.K. 1980. The structure and function of $\mathrm{C}_{4}$ vascular tissue. Bericht der Deutschen botanischen Gesellschaft 93:71-78.

DENGLER, N.G., DENGLER, R.E. \& HATTERSLEY,P.W. 1985. Differing ontogenetic origins of PCR (Kranz) sheaths in leaf blades of $\mathrm{C}_{4}$ grasses (Poaceae). American Journal of Botany 72:284-302.

ESAU, K. 1977. Plant antomy. John Wiley \& Sons, New York.

ESTELITA, M.E.M. 1992. Origin and structure of the Kranz tissue in Cyperaceae. Boletim de Botânica da Universidade de São Paulo 43:41-48.

ESTELITA, M.E.M. 1993. Anatomia dos órgãos vegetativos de Remirea maritima Aubl. (Cyperaceae). Naturalia 18:123-134.
ESTELITA-TEIXEIRA, M.E.M. \& HANDRO, W. 1987. Kranz pattern in leaf, scape and bract of Cyperus and Fimbristylis species. Revista Brasileira de Botânica 10:105-111.

HABERLANDT, G. 1914. Physiological plant anatomy. MacMillan, London.

JOHANSEN, D.A. 1940. Plant microtechnique. McGraw-Hill, New York.

KANAI, R. \& KASHIWAGI, M. 1975. Panicum milioides, a Gramineae plant having Kranz leaf anatomy without $\mathrm{C}_{4}$-photosynthesis. Plant Cell and Environment 4:161-168.

REYNOLDS, E.S. 1963. The use of lead citrate and high $\mathrm{pH}$ as an electron-opaque stain in electron microscopy. Journal of the Cell Biological 17:208-212.

RODRIGUES, A.C. \& ESTELITA, M.E.M. 2002. Primary and secondary development of Cyperus giganteus Vahl. rhizome (Cyperaceae). Revista Brasileira de Botânica 25:251-258.

SOLIDAY, C.L., KOLATTKUDY, P.E. \& DAVIS, R.W. 1979. Chemical and ultrastructural evidence that waxes associated with the suberin polymer constitute the major diffusion barrier to water vapor in potato tuber (Solanum tuberosum L.). Planta 146:607-614.

SOROS, C.L. \& DENGLER, N.G. 1998. Quantitative leaf anatomy of $\mathrm{C}_{3}$ and $\mathrm{C}_{4}$ Cyperaceae and comparisons with the Poaceae. International Journal of Plant Science 159:480-491.

SOROS, C.L. \& BRUHL, J.J. 2000. Multiple evolutionary origins of $\mathrm{C}_{4}$ photosynthesis in the Cyperaceae. In Monocots: Systematics and Evolution (K.L. Wilson \& D.A. Motison, eds.). CSIRO Publishing, Collingwood, p. 629-636.

SOROS, C.L. \& DENGLER, N.G. 2001. Ontogenetic derivation and cell differentiation in photosynthetic tissues of $\mathrm{C}_{3}$ and $\mathrm{C}_{4}$ Cyperaceae. American Journal of Botany 88:992-1005.

SPURR, A. 1969. A low-viscosity epoxy resin embedding medium for electron microscopy. Journal of Ultrastructure Research 26:32-43.

TAKEDA, T., UENO, O. \& AGATA, W. 1980. The occurrence of $\mathrm{C}_{4}$ species in the genus Rhynchospora and its significance in Kranz anatomy of the Cyperaceae. The Botanical Magazine Tokyo 93:55-65.

TAKEDA, T., UENO, O., SAMEJIMA, M. \& OHTANI, T. 1985. An investigation to the occurrence of $\mathrm{C}_{4}$ photsynthesis in the Cyperaceae from Australia. The Botanical Magazine Tokyo 98:393-411.

UENO, O. \& KOYAMA, T. 1987. Distribution and evolution of $\mathrm{C}_{4}$ syndrome in Rhynchospora (RhynchosporeaeCyperaceae). The Botanical Magazine Tokyo 100:63-85. 
UENO, O. \& SAMEJIMA, M. 1989. Structural features of NAD-malic enzyme type $\mathrm{C}_{4}$ Eleocharis an additional report $\mathrm{C}_{4}$ acid decarboxylation types of the Cyperaceae. The Botanical Magazine Tokyo 102:393-402.

UENO, O., TAKEDA, T. \& MAEDA, E. 1988. Leaf ultrastructure of $\mathrm{C}_{4}$ species possessing different Kranz anatomical types in the Cyperaceae. The Botanical Magazine Tokyo 101:141-152.

UENO, O., SAMEJIMA, M. \& KOYAMA, T. 1989. Distribution and evolution of $\mathrm{C}_{4}$ syndrome in Eleocharis, a sedge group inhabiting wet and aquatic environments, based on culm anatomy and carbon isotope rations. Annals of Botany 64:425-438.
VAN FLEET, D.S. 1950. The cell forms, and their common substance reactions, in the parenchyma vascular boundary. Bulletin of the Torrey Botanical Club 77:340-353.

WATSON, M.L. 1958. Staining of the tissue sections for electron microscopy with heavy metals. Journal of Biophysical and Biochemistry Cytology 4:475.

WELKIE,G.W. \& CALDWELL, M.1970. Leaf anatomy of species in some dicotyledon families as related to the $\mathrm{C}_{3}$ and $\mathrm{C}_{4}$ pathways of carbon fixation. Canadian Journal of Botany 48:2135-2146. 